\title{
Biochemical and Clinical Implications of Proinsulin Conversion Intermediates
}

\author{
B. D. Given, R. M. Cohen, S. E. Shoelson, B. H. Frank, A. H. Rubenstein, and H. S. Tager \\ Departments of Biochemistry and Molecular Biology, and Medicine, The University of Chicago, Chicago, Illinois 60637; \\ and Lilly Research Laboratories, Indianapolis, Indiana 46285
}

\begin{abstract}
Since a complete map of insulin-related peptides in humans requires consideration of proinsulin, $\mathrm{Arg}^{32} / \mathrm{Glu}^{33}$-split proinsulin, $\mathrm{Arg}^{65} / \mathrm{Gly}^{66}$-split proinsulin, des-Arg ${ }^{31}, \mathrm{Arg}^{32}$-proinsulin, des$\mathrm{Lys}^{64}, \mathrm{Arg}^{65}$-proinsulin, and insulin, we applied high performance liquid chromatography coupled with radioimmunoassay to investigate the formation of proinsulin conversion intermediates in vitro and in vivo. Kinetic analysis of proinsulin processing by a mixture of trypsin and carboxypeptidase $B$ (to simulate in vivo processes) revealed $(a)$ a rapid decline in proinsulin concommitant with formation of conversion intermediates, (b) formation of des$\mathrm{Arg}^{31}, \mathrm{Arg}^{32}$-proinsulin and des- $\mathrm{Lys}^{64}, \mathrm{Arg}^{65}$-proinsulin in the ratio 3.3:1 at steady state, and (c) complete conversion of the precursor to insulin during extended incubation. Studies on normal human pancreas identified a similar ratio of des- $\mathbf{A r g}^{31}, \mathbf{A r g}^{32}$-proinsulin to des-Lys ${ }^{64}, \mathrm{Arg}^{65}$-proinsulin ( 3:1), whereas two insulinomas contained sizable amounts of des- $\mathbf{A r g}^{31}, \mathrm{Arg}^{32}$-proinsulin, but barely detectable amounts of des-Lys ${ }^{64}, \mathrm{Arg}^{65}$-proinsulin. None of the tissues contained measurable quantities of $\mathrm{Arg}^{32} / \mathrm{Glu}^{33}$ or $\mathrm{Arg}^{65} / \mathrm{Gly}^{66}$-split proinsulin. Analysis of plasma from three diabetic subjects managed by the intravenous infusion of human proinsulin revealed $<\mathbf{1 \%}$ processing of the circulating precursor to conversion intermediates and no processing of the precursor to human insulin. Nevertheless, analysis of plasma from the same subjects managed by the subcutaneous infusion of proinsulin revealed $4-11 \%$ processing of the precursor to intermediates that had the properties of des-Arg ${ }^{31}, \mathrm{Arg}^{32}$-proinsulin and $\mathrm{Arg}^{65} / \mathrm{Gly}^{66}$ split proinsulin. We conclude that (a) processing of proinsulin to insulin in vivo as in vitro likely occurs by preferential cleavage at the $\mathrm{Arg}^{32}-\mathrm{Glu}^{33}$ peptide bond in proinsulin, (b) proinsulin is inefficiently processed in the vascular compartment, and (c) subcutaneous administration of the precursor can result in the formation of conversion intermediates with the potential for contributing to biological activity.
\end{abstract}

\section{Introduction}

Although the biosynthesis of insulin via limited proteolytic cleavage of proinsulin (the single-chain hormone precursor) has been recognized for almost $20 \mathrm{yr}(1-3)$, many details of the conversion process and of the physiological significance of the circulating precursor remain to be clarified. As illustrated by the

Address correspondence to Howard S. Tager, Department of Biochemistry and Molecular Biology, The University of Chicago, 920 East 58th Street, Chicago, IL 60637. 1985

Received for publication 5 March 1985 and in revised form 1 July

J. Clin. Invest.

(c) The American Society for Clinical Investigation, Inc.

$0021-9738 / 85 / 10 / 1398 / 08 \quad \$ 1.00$

Volume 76, October 1985, 1398-1405 tentative scheme of Fig. 1, conversion of proinsulin to insulin is thought to occur by a branched pathway involving $(a)$ the action of enzymes with specificities similar to those of trypsin and carboxypeptidase $\mathrm{B}$ and $(b)$ the formation of conversion intermediates that include in humans $\mathrm{Arg}^{65} / \mathrm{Gly}^{66}$-split proinsulin, $\mathrm{Arg}^{32} / \mathrm{Glu}^{33}$-split proinsulin, des-Lys ${ }^{64}, \mathrm{Arg}^{65}$-proinsulin, and des- $\mathrm{Arg}^{31}, \mathrm{Arg}^{32}$-proinsulin (4-5). The analogous des-dipeptide proinsulin intermediates have been identified by analysis of proinsulin-containing fractions produced during the commercial manufacture of bovine and porcine insulin $(4,6)$, by biosynthetic experiments involving the use of isolated pancreatic islets (7), and by in vitro studies involving the use of commercially available enzymes (8). Related forms, along with proinsulin, have been detected in large scale preparations of human insulin (9), in human insulinomas incubated with radiolabeled amino acids (1), and in human serum (10-14). Abnormal intermediates of conversion have also been identified in two families with insulin gene mutations and with familial hyperproinsulinemia (15-17). Still, the complexity of the scheme for the biosynthetic conversion of proinsulin to insulin (a complexity particularly acute in the rat, where expression of two nonallelic insulin genes results in a doubling of the number of intermediate forms [18]), the number of different endopeptidases suggested to play potential roles in the conversion process (including glandular kallikrein, cathepsin B, trypsin, kininogenase, plasminogen activator, and their related forms [19-23]), and the lack of both sensitive and discriminating methods to analyze the low amounts of proinsulin and conversion intermediates available for study, have hindered investigation in the area.

The recent availability of biosynthetic human proinsulin for biological and biochemical study has led to renewed interest in the clinical importance of the hormone precursor (24-26). A number of investigators have now developed specific radioimmunoassays for human proinsulin (27-30), studied the in vitro and in vivo biological activities of the hormone precursor (24$26,31,32$ ), and considered the efficacy of proinsulin in managing diabetic patients (26). Such uses of proinsulin, however, require consideration of proinsulin metabolism and the potential formation and measurement of conversion intermediates. We have therefore developed a combined approach to the identification of intermediates of proinsulin conversion that involves both isocratic, reverse-phase high performance liquid chromatography (HPLC), ${ }^{1}$ and specific radioimmunoassays for insulin, C-peptide, and proinsulin. Application of our methods to the study of enzyme-catalyzed proinsulin conversion, to the determination of intermediates in normal pancreatic and insulinoma tissue, and to the analysis of circulating forms resulting from proinsulin infusion in humans reveals that conversion of proinsulin to insulin, in vivo as in vitro, likely occurs by preferential cleavage at the $\mathrm{Arg}^{32}-\mathrm{Glu}^{33}$ peptide bond in the precursor and that subcutaneous, but not intravenous, infusion of proinsulin results

1. Abbreviations used in this paper: HPLC, high performance liquid chromatography. 

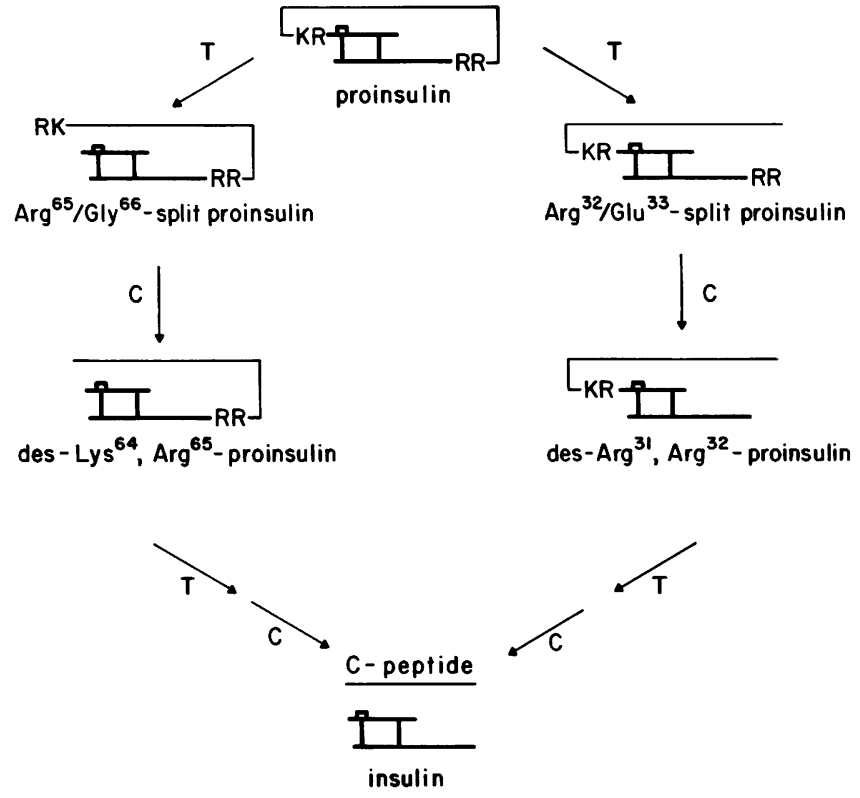

Figure 1. Scheme for the processing of proinsulin to major conversion intermediates and to insulin. The A-chains and B-chains of insulin are illustrated by heavy lines, whereas the C-peptide is illustrated by a light line. (The length of the $\mathrm{C}$-peptide is exaggerated in the projection used.) Paired dibasic amino acids at precursor conversion sites are shown explicitly and are identified by the one-letter amino acid code ( $K$, lysine; $R$, arginine). The numbering of amino acid residues assumes that the peptides are derived from humans; that is, that the $C$ peptide is 31 residues in length. The letters $T$ and $C$ identify reactions thought to be catalyzed by trypsin-like and carboxypeptidase B-like enzymes, respectively. While processing of proinsulin to the des-dipeptide proinsulin intermediates of conversion is shown in detail, processing of these intermediates to insulin is shown in an abbreviated way: cleavage of either intermediate by a trypsin-like endoprotease at the remaining paired dibasic amino acid conversion site, followed by the action of a carboxypeptidase B-like exoprotease to remove $\mathrm{COOH}$-terminal basic residues, would yield insulin plus $C$-peptide.

in the appearance of variable, but significant, amounts of proinsulin conversion intermediates in the circulation.

\section{Methods}

Enzymatic conversion of biosynthetic human proinsulin. Biosynthetic human proinsulin $(0.75 \mathrm{mg}$; provided by Lilly Research Laboratories, Indianapolis, $\mathrm{IN})$ was dissolved in $0.75 \mathrm{ml}$ of Tris buffer $(0.05 \mathrm{M}$ Tris, $0.005 \mathrm{M} \mathrm{CaCl}_{2}$ brought to $\mathrm{pH} 7.5$ with $\mathrm{HCl}$ ). Tosylphenylalanine chloromethylketone-treated trypsin $(0.9 \mu \mathrm{g}$; Worthington Biochemical Corp., Freehold, NJ) and carboxypeptidase B (18 $\mu \mathrm{g}$; Boehringer Mannheim Biochemicals, Indianapolis, IN) were added, and digestion was allowed to proceed at $22^{\circ} \mathrm{C} ; 15-\mu \mathrm{l}$ aliquots of the reaction mixture were removed at $0.25,1,3,5,10$, and $30 \mathrm{~min}$ and were added to $15-\mu 1$ portions of glacial acetic acid to stop the reaction. The mixtures were then analyzed by HPLC (see below). The proinsulin conversion intermediates des$\mathrm{Arg}^{31}, \mathrm{Arg}^{32}$-proinsulin and des- $\mathrm{Lys}^{64}, \mathrm{Arg}^{65}$-proinsulin were identified by amino acid analysis and by comparison with authentic standards. Intermediates containing dibasic amino acid residues at conversion sites $\left(\mathrm{Arg}^{32} / \mathrm{Glu}^{33}\right.$-split proinsulin and $\mathrm{Arg}^{65} / \mathrm{Gly}^{66}$-split proinsulin) were generated by incubating $0.1 \mathrm{mg}$ of biosynthetic human proinsulin with 0.12 $\mu \mathrm{g}$ of trypsin for $2 \mathrm{~min}$ at $22^{\circ} \mathrm{C}$ in $0.1 \mathrm{ml}$ of the Tris buffer described above. The reaction was stopped by the addition of glacial acetic acid and the products were separated by HPLC. The intermediates were identified by subsequent conversion to the des-dipeptide intermediates (through digestion with carboxypeptidase B and HPLC analysis) and by comparison with authentic standards.

Tissue extractions. Two human insulinomas and a specimen of normal pancreas were obtained at laparotomy, with warm ischemia times being $<15 \mathrm{~min}$; the tissues were frozen with liquid nitrogen and stored at $-70^{\circ} \mathrm{C}$. An additional specimen of pancreas from a transplant donor was obtained frozen on dry ice from The National Diabetes Research Interchange, Philadelphia, PA. Tissues were homogenized in acidified ethanol and soluble peptides were precipitated by the addition of ethanol and diethyl ether, as described (33). In each case, the precipitated material was dissolved in $5 \mathrm{ml}$ of $3 \mathrm{M}$ acetic acid and the sample was gel-filtered on a column $(2.5 \times 90 \mathrm{~cm})$ of Bio-Gel P-30 (Bio-Rad Laboratories, Richmond, CA) using the same solvent. Fractions containing $4 \mathrm{ml}$ were collected; peaks of material corresponding to proinsulin and insulin were identified by subjecting aliquots of fractions to radioimmunoassay for insulin. The higher molecular weight peak of material (containing proinsulin and intermediates of proinsulin conversion) was pooled in each case, and aliquots of these pooled fractions were analyzed by HPLC as described later.

Proinsulin infusion and purification of plasma components. Plasma from three diabetic subjects who received infusions of biosynthetic human proinsulin was obtained from studies similar to those reported previously (26). Briefly, subjects receiving pork insulin as part of their therapy were admitted to the Clinical Research Center and were treated with subcutaneous regular pork insulin to maintain euglycemia. Insulin therapy was terminated and intravenous human proinsulin was then administered to maintain the blood glucose level. Subjects were placed on a basal intravenous infusion of proinsulin for $24 \mathrm{~h}$ with bolus injections to cover meals, after which a $50-\mathrm{ml}$ specimen of blood was collected in iced tubes containing ethylenediamine tetraacetic acid $(1.25 \mathrm{mg} / \mathrm{ml})$ and aprotinin (417 U/ml; Sigma Chemical Co., St. Louis, MO). Resulting proinsulin levels in subjects 1 and 2 were 5.5 and $4.7 \mathrm{pmol} / \mathrm{ml}$, respectively; subject 3 received a bolus injection $30 \mathrm{~min}$ before sampling, resulting in a proinsulin level of $22.5 \mathrm{pmol} / \mathrm{ml}$. Subjects were then placed on subcutaneous proinsulin infusion by use of a subcutaneous insulin infusion pump (model 9100; Cardiac Pacemakers, Inc., St. Paul, MN) for an additional 24-h period and a second 50-ml specimen of blood was obtained; subcutaneous bolus injections were used to cover meals. Proinsulin levels resulting from subcutaneous infusion were $9.9,8.0$, and $9.9 \mathrm{pmol} / \mathrm{ml}$ for subjects 1,2 , and 3 , respectively. Doses of proinsulin administered over the 24-h infusion periods were 9.7 and $10.2 \mathrm{mg}$ for subject $1,8.6$ and $9.4 \mathrm{mg}$ for subject 2 , and 9.4 and $12.5 \mathrm{mg}$ for subject 3 , for the intravenous and subcutaneous routes, respectively. Mean blood glucose levels (determined at 2-h intervals during the last $8 \mathrm{~h}$ of proinsulin infusion) were 207 and $249 \mathrm{mg} / \mathrm{dl}$ for subject 1,130 and $108 \mathrm{mg} / \mathrm{dl}$ for subject 2 , and 222 and $141 \mathrm{mg} / \mathrm{dl}$ for subject 3 , again for the intravenous and subcutaneous routes of proinsulin administration, respectively. These studies received the approval of the Clinical Investigation Committee of The University of Chicago.

Plasma was separated from blood specimens immediately after collection and insulin immunoreactive material was purified by passage of the diluted plasma over columns of guinea pig anti-insulin antibodies bound to Sepharose as previously described $(16,34)$. Yields of insulin immunoreactive material exceeded $90 \%$. Control studies involving the use of insulin and proinsulin, and previous studies involving the use of abnormal intermediates of proinsulin conversion (16), showed that our antibody columns extract insulin, proinsulin, and proinsulin intermediates equivalently. Additional studies showed that proinsulin added to freshly collected blood from normal subjects and then processed as described above was not subject to proteolytic degradation nor to conversion to intermediates or insulin.

HPLC analysis and radioimmunoassays. Separation of insulin, proinsulin, and proinsulin intermediates was performed by reverse-phase HPLC using a Series 4 liquid chromatograph, ISS-100 automatic injector, LC 85B spectrophotometric detector with autocontrol, and LCI 100 recorder/integrator (all from Perkin-Elmer Corp., Norwalk, CT). Separations occurred at $21^{\circ} \mathrm{C}$ on an Ultraphere C-18 Ion-pair column (4.6 $\times 250 \mathrm{~mm}, 5 \mu \mathrm{m}$ particle size, Altex Scientific, Inc., Berkeley, CA). 
Elution buffers contained an aqueous phase of $0.012 \mathrm{M}$ triethylamine, $0.1 \mathrm{M}$ phosphoric acid, and $0.05 \mathrm{M} \mathrm{NaClO}_{4}$ (HPLC-grade, Fisher Scientific, Fair Lawn, NJ) adjusted to pH 3.0 with $\mathrm{NaOH}$, and an organic phase of acetonitrile (HPLC-grade, Fisher Scientific Co., Pittsburgh, PA) (35). The flow rate was $1 \mathrm{ml} / \mathrm{min}$.

Elution of samples (injected in $3 \mathrm{M}$ acetic acid containing 0.05-0.1 $\mathrm{mg}$ of bovine serum albumin when amounts of peptide were $<1 \mu \mathrm{g}$ ) proceeded by a series of three-stepped isocratic mixtures of the aqueous and organic phases described above. For most studies, insulin was eluted during $30 \mathrm{~min}$ at $31.0 \%$ acetonitrile; proinsulin conversion intermediates were eluted during $\mathbf{4 0} \mathrm{min}$ at $31.2 \%$ acetonitrile; proinsulin was eluted during $30 \mathrm{~min}$ at $32.5 \%$ acetonitrile. The column was then eluted by a 30 -min, linear gradient to $55 \%$ acetonitrile to remove albumin and other substances, and was equilibrated with the starting solution containing $31 \%$ acetonitrile for an additional $30 \mathrm{~min}$. All isocratic solutions were premixed to ensure reproducibility. For in vitro conversion studies and for calibration, optical absorbance was recorded at $214 \mathrm{~nm}$ and peak areas were integrated electronically. For analysis of plasma samples and of lesser amounts of material, 0.4-ml fractions of column effluent were collected in tubes containing a drop of borate buffer $\left(0.5 \mathrm{M} \mathrm{H}_{3} \mathrm{BO}_{3}\right.$ and $10 \mathrm{mg} / \mathrm{ml}$ of bovine serum albumin adjusted to $\mathrm{pH} 9.3$ with $\mathrm{NaOH}$ ). The organic solvent was removed under vacuum and the contents of the tubes were then lyophilized. The residues were dissolved in 1-ml aliquots of radioimmunoassay buffer $(0.04 \mathrm{M}$ sodium dihydrogen phosphate, $0.1 \mathrm{M} \mathrm{NaCl}, 0.6 \mathrm{mM}$ ethylmercurithiosalicylic acid, and $6 \%$ bovine serum albumin, all brought to $\mathrm{pH} 7.4$ by the addition of $\mathrm{NaOH}$ ). $\mathrm{Ra}$ dioimmunoassays for insulin (using antibody GP-1), for human C-peptide (using antibody M1230), and for human proinsulin (using antibody 18D) have been described $(30,36,37)$. Yields of immunoreactive insulin recovered from the HPLC column ranged from 70 to $90 \%$ of the material applied. Previous studies have shown that the insulin assay is relatively nondiscriminating for insulin-containing peptides (16), that the C-peptide assay requires the free $\mathrm{COOH}$-terminus of the peptide for full reactivity (36), and that the proinsulin assay depends on the $\mathrm{Arg}^{31}-\mathrm{Arg}^{32}$ linkage between the $\mathrm{COOH}$-terminus of the insulin $\mathrm{B}$ chain and the $\mathrm{NH}_{2}$-terminus of the C-peptide for ligand recognition (30).

\section{Results}

Our study of proinsulin processing began with an examination of precursor conversion by a mixture of trypsin and carboxypeptidase B. Digestion conditions (limiting trypsin and excess carboxypeptidase $B$, see ref. 8) were chosen to result in des$\mathrm{Arg}^{31}, \mathrm{Arg}^{32}$-proinsulin and des-Lys ${ }^{64}, \mathrm{Arg}^{65}$-proinsulin as intermediates in the conversion and to yield insulin as the product; analysis of the reaction mixture by reverse-phase HPLC was designed to provide both separation of substrate, intermediates, and product, and quantitation of each of these components. HPLC profiles of the reaction mixture described under Methods, after selected periods of digestion, are shown in Fig. 2. Note that (a) the preparation of biosynthetic human proinsulin contained neither insulin nor proinsulin conversion intermediates, (b) measurable amounts of des- $\mathrm{Arg}^{31}, \mathrm{Arg}^{32}$-proinsulin and des$\mathrm{Lys}^{64}, \mathrm{Arg}^{65}$-proinsulin were detected after only $15 \mathrm{~s}$ of digestion, (c) the amounts of these conversion intermediates first increased and then decreased as proinsulin was converted to insulin, and (d) conversion was essentially complete by $30 \mathrm{~min}$, even under these conditions where the molar ratio of substrate to endoprotease exceeded 2,000:1 and the concentration of trypsin was 0.5 nM. Notwithstanding the small amount of desamido human insulin detected at 36 min of elution, no evidence for degradation of the product to desoctapeptide insulin (insulin lacking residues B23 through B30) or to other material was noted. Quantitative analysis of the kinetics of proinsulin conversion (employing greater numbers of digestion periods) is provided in Fig. 3. As
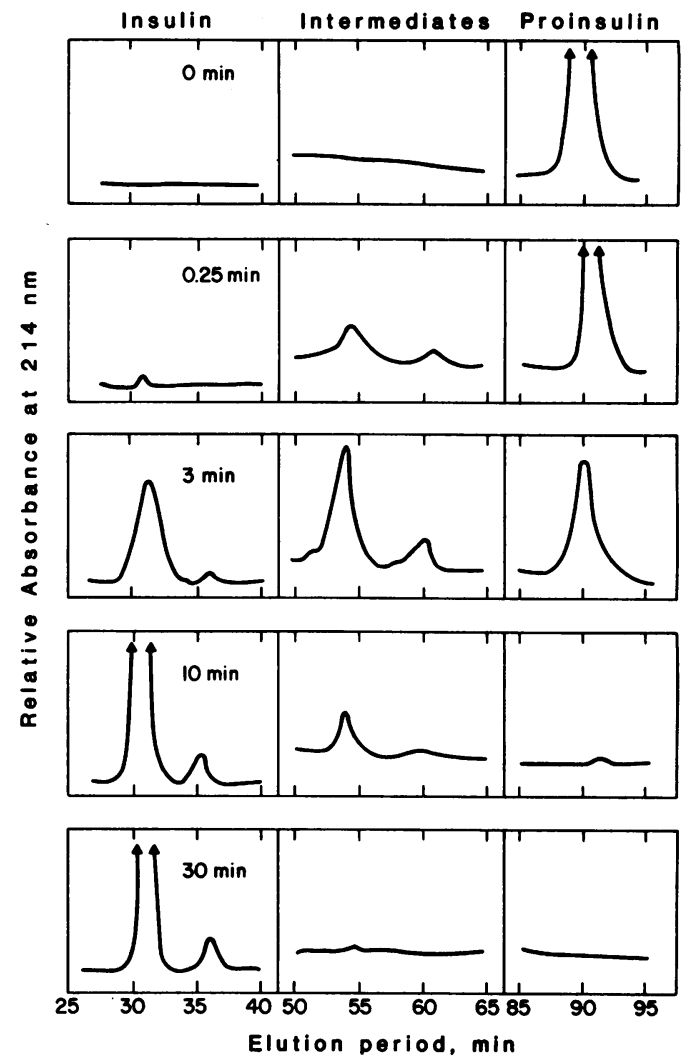

Figure 2. HPLC elution profiles of insulin, conversion intermediates, and proinsulin resulting from the incubation of human proinsulin with trypsin plus carboxypeptidase B. Recorder tracings measuring optical absorbance at $214 \mathrm{~nm}$ are shown for samples of proinsulin incubated with enzymes for the periods identified, as described in Methods. The abcissa records the period required for elution of the peptides from the reverse-phase column and is truncated in two areas; no absorbing material appeared between 40 and $50 \mathrm{~min}$ or between 65 and 85 min of elution. In each case, the height of the frame corresponds to 0.01 absorbance unit. The peak of insulin shown at $0.25 \mathrm{~min}$ of digestion corresponds to $2 \%$ of total absorbance. Peptides eluting in the left and right peaks in the area of the profile called "intermediates" were identified as des-Arg ${ }^{31}, \mathrm{Arg}^{32}$-proinsulin and des-Lys ${ }^{64}, \mathrm{Arg}^{65}$-proinsulin, respectively, by use of standards.

illustrated by the figure, the concentration of proinsulin is initially seen to drop rapidly (in synchrony with the formation of conversion intermediates) with only minimal formation of insulin. At all periods of digestion, the concentration of des- $\mathrm{Arg}^{31}, \mathrm{Arg}^{32}$ proinsulin exceeded that of des-Lys ${ }^{64}, \mathrm{Arg}^{65}$-proinsulin, with the ratio of these two intermediate forms being $\sim 3: 1$ both after short periods (when formation of insulin was minimal) and at steady state (3-5 min of digestion).

As we wished to investigate the occurrence of $\mathrm{Arg}^{32} / \mathrm{Glu}^{33}$ split proinsulin and $\mathrm{Arg}^{65} / \mathrm{Gly}^{66}$-split proinsulin (in addition to the occurrence of the related des-dipeptide proinsulin intermediates) in both tissues and the circulation, we next examined the use of reverse-phase HPLC and radioimmunoassay to differentiate among the four major intermediates of proinsulin conversion. Fig. $4 \mathrm{~A}$ illustrates the central portion of an HPLC profile resulting from $(a)$ the injection of nanogram-quantities of des- $\mathrm{Arg}^{31}{ }, \mathrm{Arg}^{32}$-proinsulin and des- $\mathrm{Lys}^{64}, \mathrm{Arg}^{65}$-proinsulin, (b) the collection of effluent fractions, and $(c)$ the analysis of eluted material by insulin, $\mathrm{C}$-peptide and proinsulin radioimmunoassay. As expected from the results of Fig. 2 (where larger amounts 


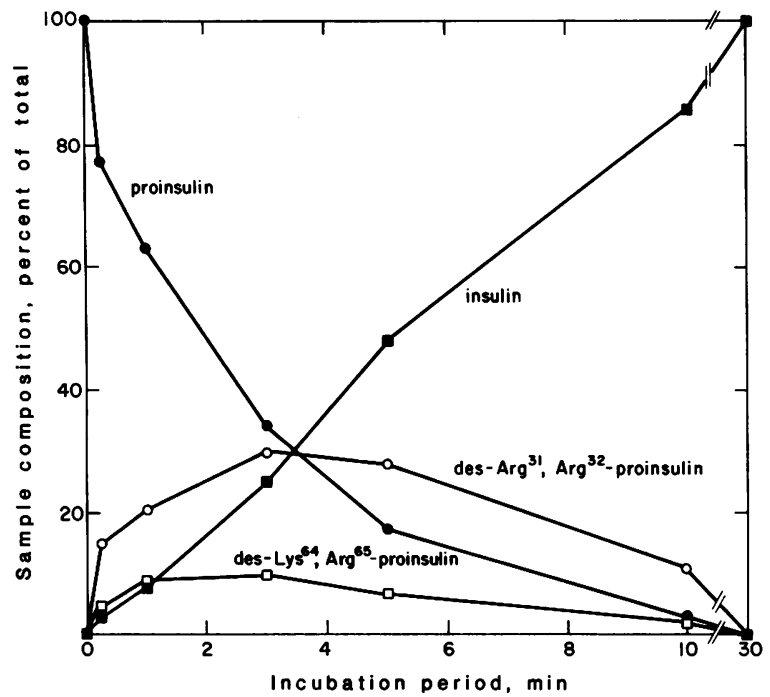

Figure 3. Quantitative analysis of proinsulin conversion to insulin by a mixture of trypsin plus carboxypeptidase B. Samples of human proinsulin incubated with trypsin plus carboxypeptidase B as described in Methods were analyzed by reverse-phase HPLC (see Fig. 2). Electronic integration of peak areas derived from measurement of optical absorbance at $214 \mathrm{~nm}$ permitted quantitative analysis of the conversion process over the 30 -min period shown. Data are plotted separately for proinsulin, des- $\mathrm{Arg}^{31}, \mathrm{Arg}^{32}$-proinsulin, des- $\mathrm{Lys}^{64}, \mathrm{Arg}^{65}$-proinsulin and insulin, and represent insulin-containing forms only; Cpeptide released during precursor processing was not considered in this analysis.

of material were quantitated by optical absorbance) and from the lack of selectivity of our radioimmunoassay for insulin, the conversion intermediates des- $\mathrm{Arg}^{31}, \mathrm{Arg}^{32}$-proinsulin and des$\mathrm{Lys}^{64}, \mathrm{Arg}^{65}$-proinsulin were well separated and readily detected as immunoreactive insulin. Also as expected, des- $\mathrm{Lys}^{64}, \mathrm{Arg}^{65}$ proinsulin (a peptide that contains the free $\mathrm{C}$-peptide $\mathrm{COOH}$ terminus and the $\mathrm{Arg}^{31}-\mathrm{Arg}^{32}$ linkage between the $\mathrm{COOH}$-terminal region of the insulin $\mathrm{B}$-chain and the $\mathrm{NH}_{2}$-terminal region of the C-peptide) reacted well in our radioimmunoassays for both C-peptide and proinsulin. On the other hand, des$\mathrm{Arg}^{31}, \mathrm{Arg}^{32}$-proinsulin (a peptide containing a blocked C-peptide $\mathrm{COOH}$-terminus and lacking the $\mathrm{Arg}^{31}-\mathrm{Arg}^{32}$ linkage) showed very poor reactivity in both assays. The separation and analysis of $\mathrm{Arg}^{32} / \mathrm{Gly}^{33}$-split proinsulin and $\mathrm{Arg}^{65} / \mathrm{Gly}^{66}$-split proinsulin by use of identical methods are illustrated in Fig. 4 B. The two peptides were well resolved and easily detected by insulin radioimmunoassay, and, again, only that peptide containing the complete $\mathrm{Arg}^{31}-\mathrm{Arg}^{32}$ linkage at the precursor conversion site (that is, $\mathrm{Arg}^{65} / \mathrm{Gly}^{66}$-split proinsulin) reacted in the proinsulin assay. In contrast to des- $\mathrm{Lys}^{64}, \mathrm{Arg}^{65}$-proinsulin, however, $\mathrm{Arg}^{65}$ / $\mathrm{Gly}^{66}$-split proinsulin showed only minimal reactivity in the assay for C-peptide; this result is consistent with the known specificity of our antibody and arises from the masking of the $\mathrm{COOH}$ terminus of the C-peptide by the dipeptide sequence $\mathrm{Lys}^{64}-\mathrm{Arg}^{65}$. It is important that the intermediates of proinsulin examined in Fig. $4 A$ and $B$ maintain unique character in their elution from the HPLC column and that, as illustrated in Fig. $4 C$, resolution is maintained during chromatography of a mixture of all four peptides. The identification of the two least-well separated intermediates, des- $\mathrm{Arg}^{31}, \mathrm{Arg}^{32}$-proinsulin and $\mathrm{Arg}^{65} / \mathrm{Gly}^{66}$ split proinsulin, is greatly enhanced by the selective reactivity of only the latter in our proinsulin radioimmunoassay.
Applications of methods for the analysis of proinsulin intermediates in human tissues proceeded with the study of both B cell tumors and normal pancreas. Use of classical methods for tissue extraction, for gel filtration of resulting insulin- and proinsulin-containing fractions, and for insulin radioimmunoassay allowed us to determine that material having the molecular weight of proinsulin and proinsulin intermediates accounted for 1.7 and $2.0 \%$ of the immunoreactive insulin in two specimens of normal pancreas and 5.3 and $5.9 \%$ of the immunoreactive insulin in two B cell tumors (data not shown); the increased relative amount of higher molecular weight material in insulinoma tissue has been reported before $(12,13,38)$. As illustrated in Fig. 5, reverse-phase HPLC analysis of $9,000 \mathrm{~mol}$ wt material from the two specimens of normal pancreas and the two B cell tumors revealed that the major fraction could be identified as proinsulin in each case and that the pattern of proinsulin conversion intermediates was surprisingly simple. In the two samples of normal tissue, des- $\mathrm{Arg}^{31}, \mathrm{Arg}^{32}$-proinsulin and des- $\mathrm{Lys}^{64}{ }^{6} \mathrm{Arg}^{65}$-proinsulin were identified in the ratio $2.7: 1$ and 3.2:1, whereas in the two B cell tumors, des-Arg ${ }^{31}-\mathrm{Arg}^{32}$-proinsulin was easily identified, but des-Lys ${ }^{64}, \mathrm{Arg}^{65}$-proinsulin was barely detectable. In no case were we able to detect $\mathrm{Arg}^{32} / \mathrm{Glu}^{33}$ split proinsulin or $\mathrm{Arg}^{65} / \mathrm{Gly}^{66}$-split proinsulin in the samples of normal or neoplastic tissue. Subsequent studies not illustrated in Fig. 5 showed, as expected, that material identified as des$\mathrm{Arg}^{31}$, $\mathrm{Arg}^{32}$-proinsulin was not detected by immunoassays di-

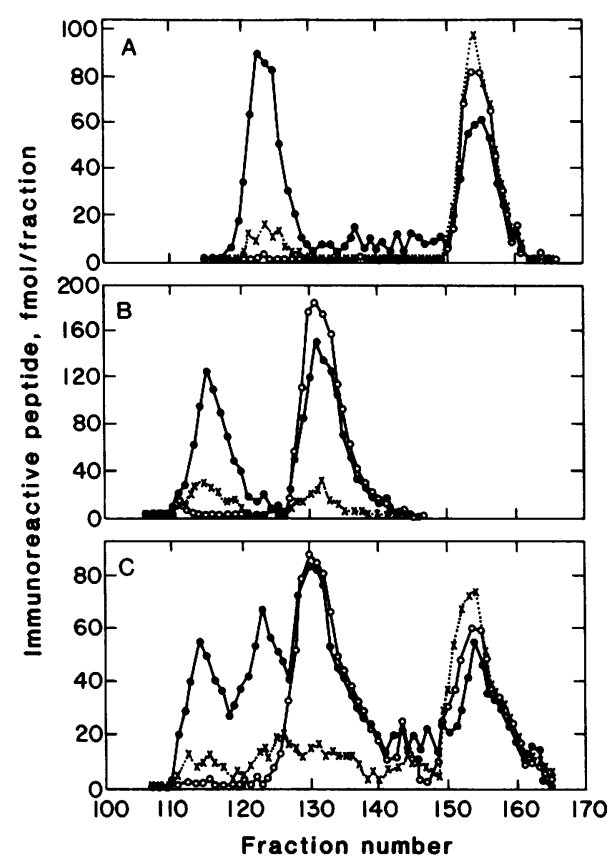

Figure 4. HPLC elution profiles of human proinsulin conversion intermediates detected by use of radioimmunoassays for insulin (๑), proinsulin (o), and C-peptide ( $x$ ). Data are shown for the central portions of the HPLC profiles (the regions in which intermediates of proinsulin conversion are eluted) only. (A) A mixture of des$\mathrm{Arg}^{31}, \mathrm{Arg}^{32}$-proinsulin (left) and des-Lys ${ }^{64}, \mathrm{Arg}^{65}$-proinsulin (right). (B) A mixture of $\mathrm{Arg}^{32} / \mathrm{Glu}^{33}$-split proinsulin (left) and $\mathrm{Arg}^{65} / \mathrm{Gly}^{66}$-split proinsulin (right). (C) A mixture of all four intermediates of conversion. The order of elution of the four intermediates in $C$ is given by $\mathrm{Arg}^{32} / \mathrm{Glu}^{33}$-split proinsulin, des- $\mathrm{Arg}^{31}, \mathrm{Arg}^{32}$-proinsulin, $\mathrm{Arg}^{65} / \mathrm{Gly}^{66}$ split proinsulin, des-Lys ${ }^{64}, \mathrm{Arg}^{65}$-proinsulin (the first through fourth peaks in $C$, from left to right, respectively). Peptides were identified by comparison with standards, as described in Methods. 


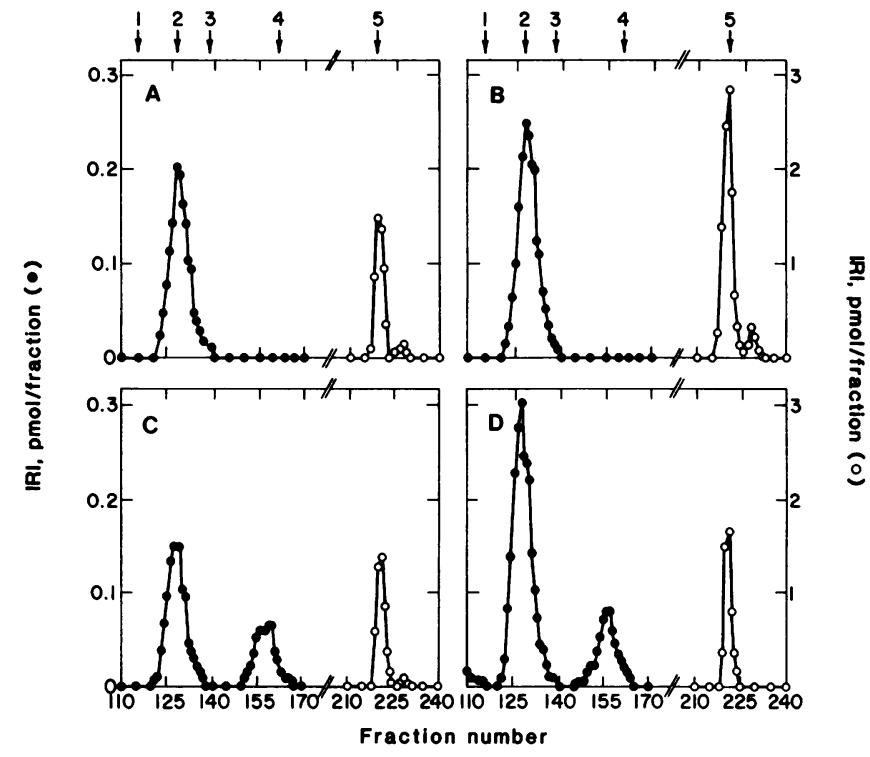

Figure 5. HPLC elution profiles of $9,000 \mathrm{~mol} \mathrm{wt}$, insulin-immunoreactive material extracted from two human $\mathrm{B}$ cell tumors $(A$ and $B)$ and from two specimens of normal human pancreas $(C$ and $D)$. Peptides were detected by use of the radioimmunoassay for insulin. Only those regions of the profile corresponding to proinsulin conversion intermediates and to proinsulin itself are shown; no immunoreactive material was detected in other regions. The elution positions of standards are shown by vertical arrows at the top of the figure: $1, \mathrm{Arg}^{32}$ / $\mathrm{Glu}^{33}$-split proinsulin; 2, des- $\mathrm{Arg}^{31}, \mathrm{Arg}^{32}$-proinsulin; 3, $\mathrm{Arg}^{65} / \mathrm{Gly}^{66}$ split proinsulin; 4, des-Lys ${ }^{64}, \mathrm{Arg}^{65}$-proinsulin; 5, proinsulin. Note the difference in scale used in plotting data corresponding to intermediates and those corresponding to proinsulin.

rected toward C-peptide or proinsulin, whereas material identified as des- $\mathrm{Lys}^{64}, \mathrm{Arg}^{65}$-proinsulin reacted well in both assays.

Because of intensified interest in the biological activities of human proinsulin (24-26) and because of the potential value of proinsulin therapy as an adjunct to insulin administration in the management of diabetes (26), we questioned whether exogenously administered proinsulin was converted either to intermediates of conversion or to insulin in the course of its use in diabetic subjects. As the route of proinsulin administration in humans and its inherent proteolytic susceptibility are matters of equal concern, conversion of the precursor as the result of both the intravenous route of administration (a route of interest mainly during controlled clinical investigation) and the subcutaneous route of administration (a route of potential importance during the management of diabetic patients) were examined. Fig. 6 shows radioimmunoassay-derived HPLC profiles of plasma components arising from the intravenous administration of biosynthetic human proinsulin to three insulin-treated diabetic subjects; the variable amounts of porcine insulin identified in the HPLC profiles arise from circulating insulin-antibody complexes. Although each of the profiles reveals a small amount of des- $\mathrm{Arg}^{31}{ }^{3} \mathrm{Arg}^{32}$-proinsulin, conversion intermediates represented $<1 \%$ of circulating proinsulin-related material in each case and human insulin was not detected. Fig. 7 illustrates HPLC profiles of plasma components arising from the subcutaneous administration of human proinsulin to the same three subjects. In contrast to findings shown in Fig. 6, subcutaneous administration of the precursor resulted in the detection of sizable amounts of proinsulin conversion intermediates in the circulation. Inter- mediates resembling both des- $\mathrm{Arg}^{31}, \mathrm{Arg}^{32}$-proinsulin and $\mathrm{Arg}^{65}$ Gly ${ }^{66}$-split proinsulin were identified in all three individuals. The sum of these intermediates plus des- $\mathrm{Lys}^{64}, \mathrm{Arg}^{65}$-proinsulin and $\mathrm{Arg}^{32} / \mathrm{Glu}^{33}$-split proinsulin represented about 4,6 , and $11 \%$ of the total proinsulin-like material in subjects 1,2 , and 3, respectively. Material resembling human insulin was detected in only a single subject (subject 3 ), where it represented $\sim 1 \%$ of total insulin immunoreactivity. Notwithstanding the variable detection of immunoreactive material in the region of the profiles of Fig. 7 spanning fractions 45 to 65 , it is clear that subcutaneous proinsulin infusion in humans results in the metabolism of the precursor to multiple physically and immunologically distinct forms.

\section{Discussion}

Our use of isocratic reverse-phase HPLC, coupled with radioimmunoassay for peptide detection, has permitted the separation and analysis of proinsulin-derived peptides of humans under a variety of circumstances. Human proinsulin, des- $\mathrm{Arg}^{31}, \mathrm{Arg}^{32}$ proinsulin, des-Lys ${ }^{64}, \mathrm{Arg}^{65}$-proinsulin, $\mathrm{Arg}^{32} / \mathrm{Glu}^{33}$-split proinsulin, $\mathrm{Arg}^{65} / \mathrm{Gly}^{66}$-split proinsulin, and insulin (as well as beef and pork insulin) are readily identified by their elution positions and their selective immunoreactivities in insulin, C-peptide, and proinsulin assays. Although our use of ion-pairing agents (triethylammonium and phosphate salts) in HPLC buffers precludes an easy assessment of relative peptide hydrophobicity, note that $\mathrm{Arg}^{32} / \mathrm{Glu}^{33}$ and $\mathrm{Arg}^{65} / \mathrm{Gly}^{66}$-split proinsulins are well separated by adsorption to the $\mathrm{C}-18$ column matrix. The separation of

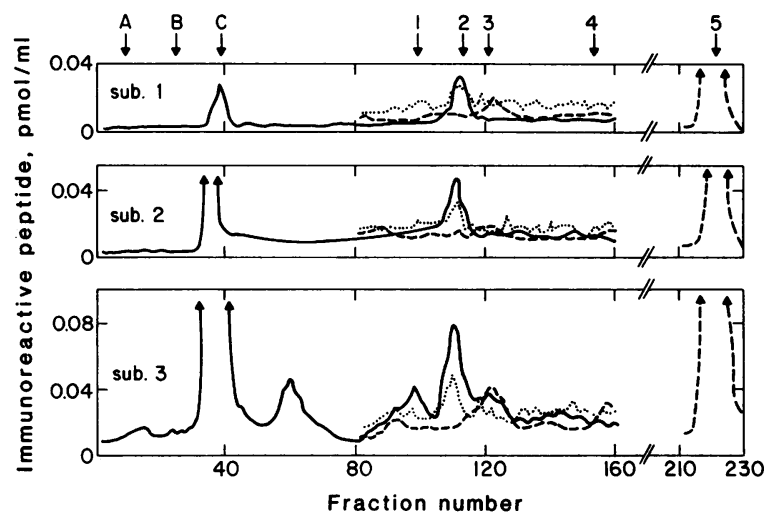

Figure 6. HPLC elution profiles of insulin-related peptides purified from the plasma of three diabetic subjects whose blood glucose levels were maintained by the intravenous infusion of human proinsulin. Procedures for immunoaffinity purification of plasma components and for HPLC analysis are described in Methods. Data are provided for material detected by radioimmunoassay for insulin $(-)$, proinsulin (---), and C-peptide $(\cdots \cdots)$. To enhance clarity of presentation, individual data points are not shown. The same ordinate scale is used in each case. The elution position of standards are indicated by vertical arrows at the top of the figure: A, bovine insulin; B, human insulin; $\mathrm{C}$, porcine insulin; $1, \mathrm{Arg}^{32} / \mathrm{Glu}^{33}$-split proinsulin; 2 , des$\mathrm{Arg}^{31}, \mathrm{Arg}^{32}$-proinsulin, 3, $\mathrm{Arg}^{65} / \mathrm{Gly}^{66}$-split proinsulin; 4, des$\mathrm{Lys}^{64}, \mathrm{Arg}^{65}$-proinsulin; 5, proinsulin. Background noise was the equivalent of $0.01 \mathrm{pmol} / \mathrm{ml}$ of insulin, $0.01 \mathrm{pmol} / \mathrm{ml}$ of proinsulin, and $0.02 \mathrm{pmol} / \mathrm{ml}$ of C-peptide. $\sim 0.06 \mathrm{pmol}$ was required for the detection of a peak of immunoreactive peptide. Note that the porcine insulin identified in each of the profiles is derived from insulin-antibody complexes present in the circulation of these insulin-treated diabetic subjects. 


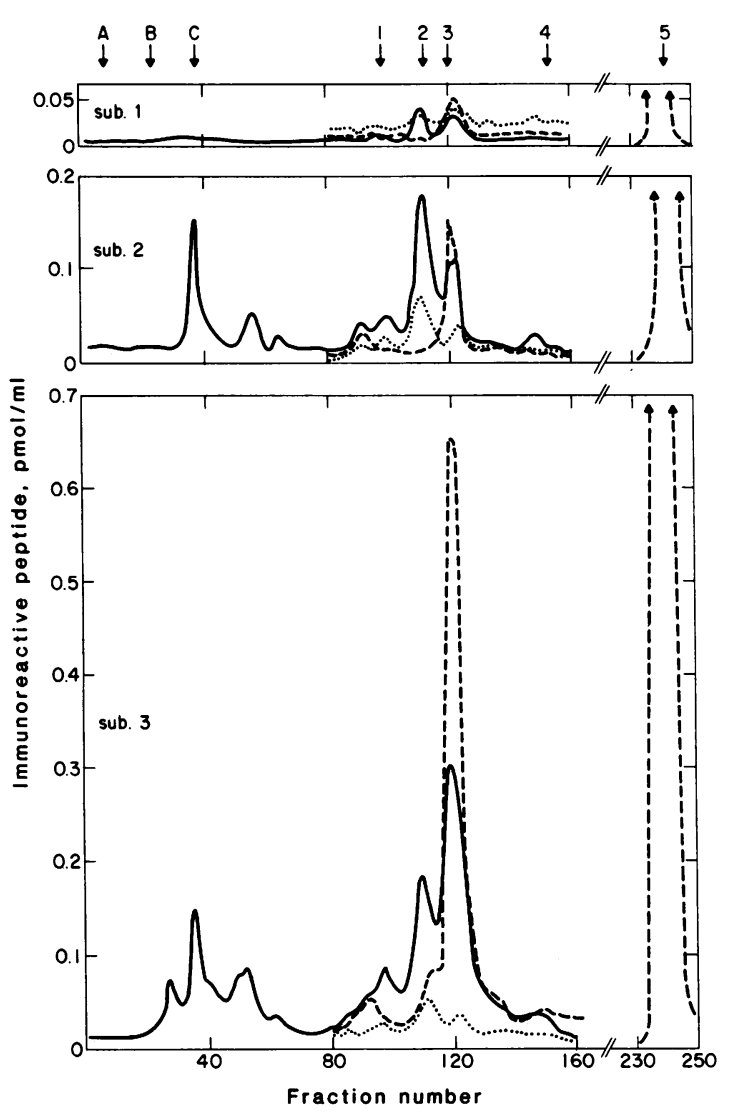

Figure 7. HPLC elution profiles of insulin-related peptides purified from the plasma of three diabetic subjects whose blood glucose levels were maintained by the subcutaneous infusion of human proinsulin. Details are provided in the legend to Fig. 6 and in Methods. Note that the ordinate scale used in Fig. 7 is contracted somewhat relative to the scale used in Fig. 6, the same ordinate scale is used in all three panels of Fig. 7, and subjects numbered 1 to 3 in the study of Fig. 7 are identical to those numbered 1 to 3 in the study of Fig. 6, respectively.

these positional isomers (like the HPLC separation of positional isomers of insulin bearing amino acid substitutions at positions B24 and B25 [35, 39]) identifies them as containing important structural differences that can alter their potential interactions with physical surfaces.

Model studies involving the conversion of human proinsulin to insulin by use of trypsin and carboxypeptidase B have demonstrated (a) the exquisite sensitivity of the $\mathrm{Arg}^{32}-\mathrm{Glu}^{33}$ and $\mathrm{Arg}^{65}$-Gly ${ }^{66}$ peptide bonds of proinsulin to cleavage by trypsin (with conversion reaching completion by $30 \mathrm{~min}$ at $22^{\circ} \mathrm{C}$ using a 2,000:1 molar ratio of substrate to enzyme) and (b) the remarkable stability of the hormone product to enzymatic degradation (see also ref. 8). More important, experiments reported here identify the ratio of the conversion intermediates des$\mathrm{Arg}^{31}, \mathrm{Arg}^{32}$-proinsulin and des- $\mathrm{Lys}^{64}, \mathrm{Arg}^{65}$-proinsulin as $~ 3: 1$ both during early periods of digestion (when the concentration of intermediates exceeds that of the product) and at the steady state (when the concentration of intermediates changes little with time). The value of this ratio during early periods indicates that the rate of cleavage of the $\mathrm{Arg}^{32}-\mathrm{Glu}^{33}$ bond in proinsulin (as assessed by the formation of des- $\mathrm{Arg}^{31}, \mathrm{Arg}^{32}$-proinsulin) exceeds that of the $\mathrm{Arg}^{65}$-Gly ${ }^{66}$ bond (as assessed by the formation of des- $\mathrm{Lys}^{64}, \mathrm{Arg}^{65}$-proinsulin) by about threefold. That this ratio is maintained at steady state (and does not decrease to unity) further indicates that the kinetic preference of the endoprotease for cleavage at the $\mathrm{Arg}^{32}-\mathrm{Glu}^{33}$ conversion site is decreased once the precursor has been processed to the two intermediate forms. Together, these results suggest that conversion of proinsulin to insulin proceeds preferentially through the righthand branch of the scheme shown in Fig. 1.

Our findings on proinsulin conversion by purified enzymes are consistent with the ratio of des- $\mathrm{Arg}^{31}, \mathrm{Arg}^{32}$-proinsulin to des$\mathrm{Lys}^{64}, \mathrm{Arg}^{65}$-proinsulin identified for intermediates extracted from normal human pancreas (2.7:1 and 3.2:1 in two samples) and with the absence of $\mathrm{Arg}^{32} / \mathrm{Glu}^{33}$ - and $\mathrm{Arg}^{65} / \mathrm{Gly}^{66}$-split proinsulins in the tissue specimens examined. It thus appears that in vivo, as in our model system, preference for cleavage of the $\mathrm{Arg}^{32}$ $\mathrm{Glu}^{33}$ peptide bond persists and that the activity of the dibasic amino acid-specific carboxypeptidase is in relative kinetic excess. Nevertheless, it should be noted that $(a)$ extensive conversion of proinsulin by the enzyme mixture in vitro yields concentrations of intermediates exceeding those of the precursor, whereas proinsulin concentrations exceed those of intermediates in both normal pancreas and B cell tumors, and $(b)$ the absence of significant amounts of des- $\mathrm{Lys}^{64}, \mathrm{Arg}^{65}$-proinsulin in insulinoma tissue cannot be simply ascribed to the decreased transit time for precursor synthesis and product secretion identified for that tissue (40).

Differences noted above emphasize the complexity of processes that serve for the conversion of proinsulin to insulin in vivo. First, while our use of trypsin as the converting endoprotease was meant to simulate (rather than to duplicate) the physiological process, the identity of the endogenous converting enzyme remains unknown (19-23). Second, while trypsin under our conditions shows the appropriate selectivity for peptide bond cleavage, the hydrogen and metal ion requirements and the physical state of the endogenous converting enzyme may well play important roles in determining its function. In fact, $(a)$ the ionic composition of the $\mathrm{B}$ cell secretion granule (a composition requiring consideration of at least $\mathrm{Zn}^{++}, \mathrm{Ca}^{++}, \mathrm{Na}^{+}$, and $\mathrm{K}^{+}$) differs considerably from that of the buffer used for our enzymatic studies, and $(b)$ the $\mathrm{pH}$ optimum for the endogenous converting enzyme is likely to be acidic rather than slightly basic, as it is for trypsin (23). Third, our enzymatic studies examined the conversion of proinsulin in dilute solution rather than at the high concentrations that occur in immature B cell secretion granules and lead eventually to crystallization of the hormone product. Indeed, studies on crystal growth have shown that proinsulin does not crystallize with zinc under conditions where the rhombohedral zinc-insulin crystal is readily formed, but that proinsulin and insulin form mixed crystals when the mole fraction of the precursor is less than about $0.4(41)$. It is thus probable that the cocrystallization of proinsulin, intermediates of proinsulin conversion, and insulin within the maturing B cell secretion granule, a process requiring decreased $\mathrm{pH}$ and the presence of $\mathrm{Zn}^{++},(a)$ causes the slowing and eventual termination of conversion, $(b)$ results in the trapping of small amounts of precursor and intermediates, and $(c)$ directs the proportions of precursor and intermediates stored in the insulin producing cell.

Since circulating proinsulin retains the potential for processing to conversion intermediates or to insulin, considerations of proinsulin metabolism have special importance when the precursor is studied for its therapeutic efficacy in diabetes. Very little processing of the precursor to proinsulin conversion intermediates and no processing of the precursor to insulin was detected during our analysis of plasma from diabetic subjects 
managed by the intravenous administration of proinsulin. This result demonstrates that $(a)$ neither the vascular compartment nor any organ to which circulating proinsulin has access (most notably the liver and kidney $[42,43]$ ) has the potential for metabolizing the precursor and releasing to the circulation more active products at a significant rate, and $(b)$ the biological activity of the intravenously administered precursor in vivo (24-26) arises solely from its specific interaction with hormone-sensitive tissues. On the other hand, our results also show that the subcutaneous administration of proinsulin (the route most often taken in clinical practice and most applicable when considering proinsulin therapy) gives rise to the appearance of variable, but significant quantities of conversion intermediates in the blood. Rates of both formation and clearance of these intermediates are important in determining their appearance under steady-state conditions. Nevertheless, the high receptor binding and biological activities of proinsulin intermediates relative to proinsulin in vitro $(6,44-46)$ and the well known direct relationship between insulin receptor occupancy and insulin degradation $(47,48)$ suggest that the rate of clearance of proinsulin intermediates would exceed that of the intact hormone precursor. Thus, it is probable that (a) proinsulin conversion intermediates identified in the plasma of proinsulin-treated subjects arise from active processes (rather than from the accumulation of compounds that might be present in the infusion solution in trace amounts), and $(b)$ these conversion intermediates have the potential for contributing to the biological activity of subcutaneously infused proinsulin.

Variable proteolysis in the subcutaneous compartment may in fact result in either degradation of the infused agent to less active material or transformation of the agent to more active products. While only the first of these processes applies to the subcutaneous administration of insulin (in the extreme case causing the syndrome of massive degradation of subcutaneous insulin [49]), both processes apply to the subcutaneous administration of proinsulin (a peptide with the potential for metabolism to both less active and more active forms). Although (a) the separate contributions of proinsulin and proinsulin conversion intermediates to maintaining glycemic control in diabetic subjects is not yet subject to accurate quantitation (and may well vary from one individual to another), and $(b)$ studies reported here have emphasized steady-state infusions and precursor processing (rather than the strict regulation of blood glucose levels), our findings form a base for considering the mechanisms by which subcutaneously infused proinsulin exerts its biological effects in vivo. Extensions of these studies will contribute to an understanding of precursor processing in peptide hormone biogenesis and to an appreciation of proteolysis in the metabolism of peptides used as therapeutic agents.

\section{Acknowledgments}

The authors thank Arlene Timosciek for assistance in preparing the manuscript, and the National Diabetes Research Interchange for providing the specimen of human tissue donor pancreas.

This work was supported by grants AM 18347, AM 13941, and AM 20595 from National Institutes of Health.

\section{References}

1. Steiner, D. F., and P. E. Oyer. 1967. The biosynthesis of insulin and a probable precursor of insulin by a human islet cell insulinoma. Proc. Natl. Acad. Sci. USA. 57:473-480.

2. Steiner, D. F., D. Cunningham, L. Spigelman, and B. Aten. 1967.
Insulin biosynthesis: evidence for a precursor. Science (Wash. DC). 157: 697-700.

3. Chance, R. E., R. M. Ellis, and W. W. Bromer. 1968. Porcine proinsulin: characterization and amino acid sequence. Science (Wash. DC). 161:165-167.

4. Steiner, D. F., O. Hallund, A. Rubenstein, S. Sho, and C. Bayliss. 1968. Isolation and properties of proinsulin, intermediate forms and other minor components from crystalline bovine insulin. Diabetes. 17: $725-736$.

5. Tager, H. S., C. Patzelt, R. K. Assoian, S. J. Chan, J. R. Duguid, and D. F. Steiner. 1980. Biosynthesis of islet cell hormones. Ann. NY Acad. Sci. 343:133-147.

6. Chance, R. E. 1971. Chemical, physical, biological and immunological studies on porcine proinsulin and related polypeptides. In Diabetes. R. R. Rodriguez and J. Vallance-Owens, editors. Excerpta Medica, Amsterdam. 292-305.

7. Steiner, D. F., J. L. Clark, C. Nolan, A. H. Rubenstein, E. Margoliash, B. Aten, and P. E. Oyer. 1969. Proinsulin and the biosynthesis of insulin. Recent Progr. Hormone Res. 25:207-270.

8. Kemmler, W., J. E. Peterson, and D. F. Steiner. 1971. Studies on the conversion of proinsulin to insulin. J. Biol. Chem. 246:6786-6791.

9. Steiner, D. F., P. E. Oyer, S. Cho, F. Melani, and A. H. Rubenstein. 1971. Structural and immunological studies on human proinsulin. In Diabetes. R. R. Rodriguez and J. Vallance-Owen, editors. Excerpta Medica, Amsterdam. 281-291.

10. Roth, J., P. Gordon, and I. Pastan. 1968. "Big insulin": a new component of plasma insulin detected by radioimmunoassay. Proc. Natl. Acad. Sci. USA. 61:138-145.

11. Melani, F. D., A. H. Rubenstein, and D, F. Steiner. 1970. Human serum proinsulin. J. Clin. Invest. 49:497-507.

12. Gutman, R. A., N. R. Lazarus, J. C. Penhos, S. Fajans, and L. Recant. 1971. Circulating proinsulin-like material in patients with functioning insulinomas. N. Engl. J. Med. 284:1003-1008.

13. Sherman, B. M., S. Pek, S. S. Fajans, J. C. Floyd, Jr., and J. W. Conn. 1972. Plasma proinsulin in patients with functioning pancreatic islet cell tumors. J. Clin. Endocrinol. Metab. 3:271-280.

14. De Haën, C., S. A. Little, J. M. May, and R. M. Williams. 1978. Characterization of proinsulin-insulin intermediates in human plasma. J. Clin. Invest. 62:727-737.

15. Gabbay, K. H., K. De Luca, J. N. Fisher, M. E. Mako, and A. H. Rubenstein. 1976. Familial hyperproinsulinemia: an autosomal dominant defect. N. Engl. J. Med. 294:911-915.

16. Robbins, D. C., P. M. Blix, A. H. Rubenstein, Y. Kanazawa, K. Kosaka, and H. S. Tager. 1981. A human proinsulin variant at arginine 65. Nature (Lond.). 291:679-681.

17. Robbins, D. C., S. E. Shoelson, A. H. Rubenstein, and H. S. Tager. 1984. Familial hyperproinsulinemia: two families secreting indistinguishable type II intermediates of proinsulin conversion. J. Clin. Invest. 73:714-719.

18. Clark, J. L., and D. F. Steiner. 1969. Insulin biosynthesis in the rat: demonstration of two proinsulins. Proc. Natl. Acad. Sci. USA. 62: 278-285.

19. Ole-Moi Yoi, O., G. S. Pinkus, J. Spragg, and K. F. Austin. 1979. Identification of human glandular kallikrein in the beta cell of the pancreas. N. Engl. J. Med. 300:1289-1294.

20. Virji, M. A., J.-D. Vassalli, R. D. Estensen, and E. Reich. 1980. Plasminogen activator of islets of Langerhans: modulation by glucose and correlation with insulin production. Proc. Natl. Acad. Sci. USA. 77: 875-879.

21. Docherty, K., R. J. Carroll, and D. F. Steiner. 1982. Conversion of proinsulin to insulin: involvement of a 31,000 molecular weight thiol protease. Proc. Natl. Acad. Sci. USA. 79:4613-4617.

22. Powers, C. A., and A. Nasjletti. 1982. A novel kinin-generating protease (kininogenase) in the porcine anterior pituitary. J. Biol. Chem. 257:5594-5600.

23. Docherty, K., and D. F. Steiner. 1982. Posttranslational proteolysis in polypeptide hormone biosynthesis. Annu. Rev. Physiol. 44:625-638.

24. Revers, R. R., R. Henry, L. Schmeiser, O. Kolterman, R. Cohen, 
R. Bergenstahl, K. Polonsky, J. Jaspan, A. H. Rubenstein, B. Frank, J. Galloway, and J. M. Olefsky. 1984. The effects of biosynthetic human proinsulin on carbohydrate metabolism. Diabetes. 33:762-770.

25. Henry, R., L. Schmeiser, O. Kolterman, R. Cohen, A. Rubenstein, B. Frank, J. Galloway, and J. M. Olefsky. 1984. Biosynthetic human insulin and proinsulin have additive but not synergistic effects on total body glucose disposal. J. Clin. Endocrinol. Metab. 58:1094-1098.

26. Bergenstahl, R. M., R. M. Cohen, E. Lever, K. Polonsky, J. Jaspan, P. M. Blix, R. Revers, J. M. Olefsky, O. Kolterman, D. Steiner, A. Cherrington, B. Frank, J. Galloway, and A. H. Rubenstein. 1984. The metabolic effects of biosynthetic human proinsulin in individuals with Type I diabetes. J. Clin. Endocrinol. Metab. 58:973-979.

27. Heding, L. G. 1977. Specific and direct radioimmunoassay for human proinsulin in serum. Diabetologia. 13:467-474.

28. Rainbow, S. J., J. S. Woodhead, D. K. Yue, S. D. Luzio, and C. N. Hales. 1979. Measurement of human proinsulin by an indirect two-site immunoradiometric assay. Diabetologia. 17:229-234.

29. Cohen, R. M., T. Nakabayashi, P. M. Blix, P. A. Rue, S. E. Shoelson, M. A. Root, B. H. Frank, R. R. Revers, and A. H. Rubenstein. 1985. A radioimmunoassay for circulating human proinsulin. Diabetes. 34:84-91.

30. Cohen, R. M., S. Provow, T. Nakabayashi, P. Blix, P. Rue, R. S. Gray, M. Root, B. H. Frank, J. Jaspan, H. S. Tager, and A. H. Rubenstein. 1984. Site-specific radioimmunoassay in the evaluation of circulating proinsulin and its intermediates. Clin. Res. 32:518A.

31. Peavy, D. E., J. D. Abram, B. H. Frank, and W. C. Duckworth. 1984. In vitro activity of biosynthetic human proinsulin. Diabetes. 33: 1062-1067.

32. Podlecki, D. A., B. H. Frank, and J. M. Olefsky. 1984. In vitro characterization of biosynthetic human proinsulin. Diabetes. 33:111118.

33. Tager, H., B. Given, D. Baldwin, M. Mako, J. Markese, A. Rubenstein, J. Olefsky, M. Kobayashi, O. Kolterman, and R. Poucher. 1979. A structurally abnormal insulin causing human diabetes. Nature (Lond.). 281:122-125.

34. Given, B. D., M. E. Mako, H. S. Tager, D. Baldwin, J. Markese, A. H. Rubenstein, J. Olefsky, M. Kobayashi, O. Kolterman, and R. Poucher. 1980. Diabetes due to secretion of an abnormal insulin. $N$. Engl. J. Med. 302:129-135.

35. Shoelson, S., M. Haneda, P. Blix, A. Nanjo, T. Sanke, K. Inouye, D. Steiner, A. Rubenstein, and H. Tager. 1983. Three mutant insulins in man. Nature (Lond.). 302:540-543.
36. Faber, O. K., C. Binder, J. Markussen, L. G. Heding, V. K. Naithani, H. Kuzuya, P. M. Blix, D. L. Horwitz, and A. H. Rubenstein. 1978. Characterization of seven C-peptide antisera. Diabetes. 27(Suppl. 1):170-177.

37. Starr, J. L., D. L. Horwitz, A. H. Rubenstein, and M. G. Mako. 1979. Insulin, proinsulin and C-peptide. In Methods of Human Radioimmunoassay. G. E. Jaffe and H. R. Behrman, editors. Academic Press, Inc., New York. 613-629.

38. Alsever, R. N., J. P. Roberts, J. G. Gerber, M. E. Mako, and A. H. Rubenstein. 1975. Insulinoma with low circulating insulin levels: the diagnostic value of proinsulin measurements. Ann. Intern. Med. 82: 347-350.

39. Shoelson, S., M. Fickova, H. Haneda, A. Nahum, G. Musso, E. T. Kaiser, A. Rubenstein, and H. Tager. 1983. Identification of a mutant human insulin predicted to contain a serine for phenylalanine substitution. Proc. Natl. Acad. Sci. USA. 80:7390-7394.

40. Creutzfeldt, C., N. S. Track, and W. Creutzfeldt. 1973. In vitro studies of the rate of proinsulin and insulin turnover in seven human insulinomas. Eur. J. Clin. Invest. 3:371-384.

41. Steiner, D. F. 1973. Cocrystallization of proinsulin and insulin. Nature (Lond.). 243:528-530.

42. Rubenstein, A. H., L. A. Pottenger, M. Mako, G. S. Getz, and D. F. Steiner. 1972. The metabolism of proinsulin and insulin by the liver. J. Clin. Invest. 51:912-921.

43. Katz, A. H., and A. H. Rubenstein. 1973. Metabolism of proinsulin, insulin, and C-peptide in the rat. J. Clin. Invest. 52:1113-1121.

44. Yu, S. S., and A. E. Kitabchi. 1973. Biological activity of proinsulin and related polypeptides in fat tissue. J. Biol. Chem. 248:3753-3761.

45. Robbins, D. C., H. S. Tager, and A. H. Rubenstein. 1984. Biological and clinical importance of proinsulin. N. Engl. J. Med. 310:11651175.

46. Frank, B. H., A. H. Pekar, C. S. Hooker, D. E. Peavy, M. R. Brunner, and W. C. Duckworth. 1984. Preparation and characterization of split forms of human proinsulin. Diabetologia. 27:276A.

47. Terris, S., and D. F. Steiner. 1975. Binding and degradation of ${ }^{125}$ I-insulin by rat hepatocytes. J. Biol. Chem. 250:8389-8398.

48. Terris, S., and D. F. Steiner. 1976. Retention and degradation of ${ }^{125} \mathrm{I}$-insulin by perfused rat livers. J. Clin. Invest. 57:885-896.

49. Paulsen, E. P., J. W. Courtney, and W. C. Duckworth. 1979. Insulin resistance caused by massive degradation of subcutaneous insulin. Diabetes. 28:640-645. 